\title{
Altered Pattern of TCR/CD3-mediated Protein-tyrosyl Phosphorylation in T Cells from Patients with Systemic Lupus Erythematosus Deficient Expression of the T Cell Receptor Zeta Chain
}

\author{
Stamatis-Nick C. Liossis, ${ }^{\star \ddagger}$ Xuan Z. Ding, ${ }^{\star}$ Greg J. Dennis,, and George C. Tsokos ${ }^{\star \ddagger}$ \\ *Department of Clinical Physiology, Walter Reed Army Institute of Research, Washington, DC 20307-5100; ${ }^{\ddagger}$ Department of Medicine, \\ Uniformed Services University of the Health Sciences, Bethesda, Maryland 20814; and ${ }^{\S}$ Rheumatology Service, Walter Reed Army Medical \\ Center, Washington, DC 20307
}

\begin{abstract}
Cellular immunity aberrations in patients with SLE are underscored by the abnormal early $\mathrm{Ag}$ receptor-mediated lymphocyte signal transduction pathway. To further characterize the $T$ cell receptor (TCR)/CD3-initiated signaling defects, we studied 22 patients with SLE, 12 patients with other systemic rheumatic diseases, and 14 normal donors. The early (1 min) TCR/CD3-mediated tyrosine phosphorylation of cellular proteins with a molecular size between 36 and $64 \mathrm{kD}$ was increased in 15 of 21 SLE patients, compared to normal or disease control subjects. The deficiency or absence of a band with a molecular size of $\sim 16 \mathrm{kD}$ in the immunoblots of SLE patients led us to investigate the expression of the TCR $\zeta$ chain. In immunoblots using anti- $\zeta$ antibodies we found that 10 of 22 lupus patients tested lacked the expression of TCR $\zeta$, which was always present in control subjects $(P<0.001)$. Flow cytometric studies using permeabilized cells confirmed the deficiency or absence of the TCR $\zeta$ chain in lupus T cells. Using Northern blots we found that for eight patients tested, the TCR $\zeta$ mRNA was missing in three, decreased in three, and apparently normal in two patients $(P<0.003)$, but was always present in control subjects. Reverse transcriptase-PCR verified Northern blot results. We conclude that $\mathrm{TCR} \zeta$ chain expression is either decreased or absent in the majority of patients with SLE, but not in patients with other systemic rheumatic diseases, regardless of disease activity, treatment status, or clinical manifestations. The previously described increases in TCR-initiated $\mathrm{Ca}^{2+}$ responses and the herein described increases in TCR-induced protein tyrosine phosphorylation and deficient TCR $\zeta$ expression may represent intrinsic defects modulating lupus T cell function. (J. Clin. Invest. 1998. 101:1448-1457.) Key words: human autoimmunity • lymphocyte signaling • tyrosine phosphorylation $\bullet$ antigen receptor • signal transduction
\end{abstract}

\section{Introduction}

$\mathrm{T}$ lymphocytes use a cell surface multisubunit structure, the $\mathrm{T}$ cell receptor (TCR $)^{1 / C D} 3$ complex, as an antigen-specific rec-

Address correspondence to Dr. George C. Tsokos, Walter Reed Army Institute of Research, Department of Clinical Physiology, Building 40, Room 3078, Washington, DC 20307-5100. Phone: 202782-9146; FAX: 202-782-3160; E-mail: gtsokos@usa.net

Received for publication 11 August 1997 and accepted in revised form 22 January 1998.

The Journal of Clinical Investigation

Volume 101, Number 7, April 1998, 1448-1457

http://www.jci.org ognition site. The clonotypic TCR $\alpha / \beta$ (or $\gamma / \delta$ ) chains are responsible for specific antigen binding, but they are unable to transmit any intracellular signals due to the very short cytoplasmic stretches they possess. Signal transduction is carried out by a nonpolymorphic $\mathrm{T}$ lineage-specific heterooligomer, the CD3 molecule, which is noncovalently associated with the Ag-binding TCR chains, as well as with the TCR $\zeta$ chain dimer. The extended cytoplasmic domains of the CD3- $\gamma,-\delta$, $-\epsilon$, and $\mathrm{TCR} \zeta$ polypeptides contain the signal transducing module immunoreceptor tyrosine-based activation motif (ITAM) in one (for each CD3 chain) or three (for each TCR $\zeta$ ) copies, to a total of 10 ITAMs per TCR/CD3 complex. The ability of tyrosine residues within an ITAM to undergo reversible phosphorylation is the essence of the early signal transduction pathway. Events that closely mimic the physiologic cascade initiated by Ag occur when an anti-CD3 antibody is used to ligate the TCR/CD3 complex. The subsequent immediate phosphorylation and activation of several cytoplasmic protein tyrosine kinases (PTK) and of their substrates leads to intracytoplasmic events, such as the mobilization of intracellular $\mathrm{Ca}^{2+}$, activation of key enzymes, gene transcription, cytokine synthesis, and release, proliferation, activation, or apoptosis $(1,2)$.

T cells from patients with SLE display multiple, frequently opposing abnormalities, including decreased cytotoxic cell function, increased helper activity, abnormal cytokine production, and the presence of unusual T cell subpopulations $(3,4)$. Work from this laboratory has shown that in SLE patients the TCR/CD3 signal transduction machinery is hyperactive in a disease-specific mode (5). In fresh peripheral T cells and in T cell lines, cross-linking of the TCR/CD3 complex led to a diseasespecific increase in the intracytoplasmic concentration of free $\mathrm{Ca}^{2+}\left(\left[\mathrm{Ca}^{2+}\right]_{\mathrm{i}}\right)$ responses that originated from the intracellular $\mathrm{Ca}^{2+}$ stores. Interestingly, this finding did not characterize any particular $\mathrm{T}$ cell subpopulation. Recently, we have demonstrated that Ag receptor-mediated (surface $\operatorname{IgM}$ and $\operatorname{IgD}$ ) signaling in $\mathrm{B}$ cells from lupus patients also leads to a diseasespecific increase in $\left[\mathrm{Ca}^{2+}\right]_{\mathrm{i}}$ responses that is correlated with significant increases of tyrosyl phosphorylation of cellular proteins with an apparent molecular size between 36 and $64 \mathrm{kD}(6)$.

The purpose of this study was to investigate whether an abnormality in the antigen-receptor-initiated early protein ty-

1. Abbreviations used in this paper: $\left[\mathrm{Ca}^{2+}\right]_{\mathrm{i}}$, intracytoplasmic concentration of free $\mathrm{Ca}^{2+}$; HRPO, horseradish peroxidase; ITAM, immunoreceptor tyrosine-based activation motif; NK, natural killer; PE, phycoerythin; PMR, polymyalgia rheumatica; PTK, protein tyrosine kinase; RT, reverse transcriptase; TCR, T cell receptor. 
rosine phosphorylation is part of the dysregulated signal transduction pathway in lupus T cells.

\section{Methods}

Patients and controls. 22 patients fulfilling the American College of Rheumatology classification criteria for lupus (7) (mean age \pm SD $=$ $47 \pm 15 \mathrm{yr}$, range $21-77 \mathrm{yr}, 20$ female and 2 male) were studied. 14 patients were on prednisone, 13 on hydroxychloroquine, 6 were receiving cytotoxic medications ( 1 on cyclophosphamide, 4 on azathioprine, and 1 on methotrexate), and 2 patients were receiving no treatment. 8 of the patients were Caucasian, 13 African American, and 1 Hispanic. Patients on prednisone were studied at least $24 \mathrm{~h}$ after their last dose. 12 additional patients (disease-control group) with other rheumatic diseases ( 7 with RA, 1 with primary Sjögren's syndrome, 1 with osteoarthritis, 1 with psoriatic arthritis, 1 with polymyalgia rheumatica [PMR], and 1 with Takayasu's arteritis, mean age $\pm S D=53 \pm 15 \mathrm{yr}$, range $25-77 \mathrm{yr}, 11$ women and $1 \mathrm{man})$. Six were receiving prednisone and eight were on methotrexate. 14 normal volunteers (normal-control group) were also analyzed. Disease activity for the SLE patients was determined using the SLEDAI scoring system (8). The protocol of the study was approved by the Health Use Committee of the Walter Reed Army Medical Center, and written informed consent was obtained from all participating patients.

Cells and antibodies. Heparinized peripheral venous blood was obtained from the study subjects. PBMCs enriched in T cells were obtained as described previously (6). The percentage of $\mathrm{T}$ cells in the obtained subpopulation in all cases was $>90 \%$ as determined by using an Epics Elite (Coulter, Hialeah, FL) flow cytometer. Cells were rested overnight in RPMI 1640 supplemented with $2 \mathrm{mM}$ glutamine, $100 \mathrm{mg} / \mathrm{ml}$ streptomycin, $100 \mathrm{U} / \mathrm{ml}$ penicillin, $25 \mathrm{mM}$ Hepes, and $10 \%$ heat-inactivated FCS ( $\mathrm{pH}$ 7.4). The murine anti-CD3 mAb OKT3 (Ortho Biotech, Inc., Raritan, NJ) was used for cell stimulation. The antiphosphotyrosine mAb 4G10 (horseradish peroxidase [HRPO] conjugated) was purchased from Upstate Biotechnology Inc. (Lake Placid, NY), the murine anti-TCR $\zeta \mathrm{mAb}$ (clone 6B10.2) was from Santa Cruz Biotechnology (Santa Cruz, CA), and the rabbit polyclonal anti-human TCR $\zeta 387$ (and anti-TCR $\eta$ ) was a generous gift from Dr. L.E. Samelson (National Institutes of Health, Bethesda, MD). The goat anti-mouse antiserum M-6149 was purchased from Sigma Chemical Co. (St. Louis, MO).

Immunoblotting and immunoprecipitation. Five million PBMCs enriched in T cells were stimulated with $10 \mu \mathrm{g} / \mathrm{ml} \mathrm{OKT} 3$ for 1 or 2 $\min$ at $37^{\circ} \mathrm{C}$. To stop the reaction, $1 \mathrm{ml}$ of ice-cold stop buffer was added $\left(10 \mathrm{mM}\right.$ Tris, $50 \mathrm{mM} \mathrm{NaCl}, 50 \mathrm{mM} \mathrm{NaF}, 0.1 \mathrm{mM} \mathrm{Na}_{3} \mathrm{VO}_{4}, 5 \mathrm{mM}$ EDTA, $30 \mathrm{mM}$ sodium pyrophosphate, $1 \mathrm{mM}$ PMSF, $2 \mu \mathrm{g} / \mathrm{ml}$ leupeptin, and $2 \mu \mathrm{g} / \mathrm{ml}$ aprotinin), and whole cell lysates were obtained in a $1 \%$ Nonidet P-40 (Sigma Chemical Co.) lysis buffer as described previously (6). Electrophoretically analyzed proteins ( $20 \mu \mathrm{g} / \mathrm{lane})$ were transferred on Immobilon nitrocellulose pure membranes (Millipore, Bedford, MA), blocked, and subsequently immunoblotted with the antiphosphotyrosine HRPO-conjugated 4G10 mAb (1:1,000). Detection was performed using the HRPL kit (National Diagnostics, Atlanta, GA). For the detection of TCR $\zeta$ chain, the murine monoclonal $6 \mathrm{~B} 10.2$ or the rabbit polyclonal 387 antibodies were used first, and subsequently the blots were incubated with a sheep anti-mouse HRPO-conjugated $\mathrm{F}\left(\mathrm{ab}^{\prime}\right)_{2}$ or with a donkey anti-rabbit HRPO-conjugated antibody, respectively (both were purchased from Amersham, Arlington Heights, IL), and developed as above. To evaluate equal loading of the lanes with protein, membranes were stripped in a solution of $100 \mathrm{mM} 2$-mercaptoethanol, $2 \%$ SDS, and $62.5 \mathrm{mM}$ Tris$\mathrm{HCl}(\mathrm{pH} 6.8)$ at $70^{\circ} \mathrm{C}$ for $45 \mathrm{~min}$, and reblocked and reblotted with appropriate control mAbs.

To immunoprecipitate the TCR $\zeta$ chain, $500 \mu \mathrm{g}$ total protein (in $500 \mu \mathrm{l}$ lysis buffer) of precleared cell lysate obtained as above was incubated on ice for $1 \mathrm{~h}$ with $2 \mu \mathrm{l}$ of the rabbit polyclonal anti-human $\mathrm{TCR} \zeta$ antibody $387.100 \mu \mathrm{l}$ of a $50 \%$ slurry of protein A/G PLUS aga- rose (Santa Cruz Biotech.) were added to capture immune complexes and incubated overnight at $4{ }^{\circ} \mathrm{C}$ on a rotator. Agarose-bound immune complexes were collected, washed three times (each with $500 \mu \mathrm{l}$ of stop buffer, lysis buffer, and Tris wash buffer), and the pellet was boiled for 5 min with $50 \mu \mathrm{l}$ of Laemmli sample buffer. Agarose was discarded, the supernatants were brought to a final concentration of $5 \%$ with 2-mercaptoethanol, and incubated at $37^{\circ} \mathrm{C}$ for $1 \mathrm{~h}$. Electrophoretic protein fractionation of equal sample volumes $(25 \mu \mathrm{l}$ of sample per lane) was followed by transfer to membranes and immunoblotting with a murine anti-human TCR $\zeta$ mAb (6B10.2). Detection was performed as described above. Densitometric measurements were performed using a DC 40 camera and analyzed with the Digital Science 1D program (Eastman Kodak Co., Rochester, NY).

Flow cytometry. The expression of cell surface markers and of $\mathrm{TCR} \zeta$ was examined in partially permeabilized, mildly fixed PBMC using a FACScan ${ }^{\circledR}$ (Becton-Dickinson, Mountain View, CA) flow cytometer as described previously (9). Briefly, $10^{6}$ PBMCs were washed three times in ice-cold PBS, and mildly fixed in $0.01 \%$ paraformaldehyde for $20 \mathrm{~min}$ on ice. Digitonin (Sigma Chemical Co.) was added at $10 \mu \mathrm{g} / \mathrm{ml}$ final, for $5 \mathrm{~min}$ on ice, and the efficiency of cell permeabilization was confirmed with the trypan blue exclusion method under a light microscope (always $>99 \%$ ). Cells were incubated with $2 \mu \mathrm{g}$ of the murine anti-human $\mathrm{TCR} \zeta 6 \mathrm{~B} 10.2 \mathrm{mAb}$ (or the MOPC 21 isotypic IgG1 mAb control [Sigma Chemical Co.]) for $30 \mathrm{~min}$ on ice, after having been incubated previously for $30 \mathrm{~min}$ on ice with an excess $(50 \times)$ concentration of purified human IgG (Cappel; ICN Pharmaceuticals, Aurora, $\mathrm{OH}$ ) to block nonspecific Fc binding sites. Then, cells were washed twice with ice-cold PBS $0.05 \%$ Tween, and further incubated with $4 \mu \mathrm{l}$ of goat anti-mouse FITC-conjugated antibodies (Becton-Dickinson) for $30 \mathrm{~min}$ on ice. After washing three times with ice-cold $\mathrm{PBS} / 1 \%, \mathrm{FBS} / 0.1 \% \mathrm{NaN}_{3}$, cells were incubated with excess mouse $\operatorname{IgG}(50 \times)$ for $30 \mathrm{~min}$ (S25 Mouse Serum; Chemicon, Temecula, CA) on ice to block the remaining anti-mouse binding sites. Cells were washed again, incubated with the proper murine $\mathrm{mAb}$ against cell surface markers, and fixed in 1\% paraformaldehyde in PBS before analysis. All the latter mAbs were phycoerythrin (PE) conjugated. The anti-CD3-PE, anti-CD4-PE, anti-CD8-PE (Becton-Dickinson), and anti-CD45RO-PE (Caltag Laboratories, Burlingame, CA) were used for identification of $T$ cell subsets. The murine anti$\mathrm{CD} 16-\mathrm{PE} \mathrm{mAb}$ was used to identify natural killer (NK) cells, and the anti-CD14-PE and anti-CD20-PE mAb (Becton-Dickinson) were used as markers for TCR $\zeta$-negative cells (monocytes and B cells) and as monitors of efficient Fc blocking.

Fixed nonpermeabilized cell samples were also stained, either with anti-CD3-PE alone or with anti-CD3-PE and anti-CD7-FITC, to measure the intensity of CD3 expression on T cells. Detection of CD3 expression on $\mathrm{T}$ cells in this system represents $\mathrm{CD} 3 \epsilon$ chain expression, according to the specificity of the anti-CD3-PE mAb used. Results were analyzed using the CellQuest (Becton Dickinson, Rutherford, NJ) analysis software.

Flow cytometric $\left[\mathrm{Ca}^{2+}\right]_{i}$ measurement. The OKT3-induced (after goat anti-mouse cross-linking) changes of $\left[\mathrm{Ca}^{2+}\right]_{i}$ in negatively selected and Indo-1 acetoxy methylester- (Molecular Probes, Eugene, OR) loaded fresh peripheral $\mathrm{T}$ cells from lupus patients and control individuals were determined as described previously (5). A heliumcadmium air-cooled UV laser-equipped Epics Elite (Coulter Corp.) flow cytometer was used, and results were analyzed using the MultiTime analysis software (Phoenix Flow Systems, San Diego, CA).

Proliferation assays. Plastic tissue culture plates (96-well, round bottom) (Falcon Labware, Cockeysville, MD) were covered with OKT3 $(0.1,1.0,10.0$, and $100.0 \mu \mathrm{g} / \mathrm{ml}$ in PBS) or with identical concentrations of UPC10 isotypic IgG2a control mAb (Sigma Chemical Co.). PBMCs $\left(2 \times 10^{5}\right.$ cells $)$ in $0.2 \mathrm{ml}$ from patients with SLE and from healthy volunteers were incubated in triplicate in OKT3-, UPC10-, or PBS-covered wells, for 2, 3, or $4 \mathrm{~d}$. The percentage of T cells in the PBMC population was predetermined with flow cytometry, and only patients and controls with comparable $\mathrm{CD}^{+}$cell populations were included. Cultures were pulsed with $1 \mu \mathrm{Ci}$ of $\left[{ }^{3} \mathrm{H}\right]$ thymidine for the 
last $18 \mathrm{~h}$. Incubation for $3 \mathrm{~d}$ at $10.0 \mu \mathrm{g} / \mathrm{ml}$ of OKT3 was optional. Cells were harvested using a semiautomatic cell harvester (Skatron Instruments, Sterling, VA) on glass fiber filters and radioactivity was measured using a 1205 Betaplate liquid scintillation counter (LKB Wallac, Turku, Finland). For triplicate wells, one SD was always $<10 \%$ of the mean. Results are expressed as the mean \pm SEM $\Delta \mathrm{cpm}$. The effect of equal concentrations of the $\operatorname{IgG} 2 \mathrm{a}$ isotypic control $\mathrm{mAb}$ (again in triplicate wells) was always negligible.

Reverse transcriptase (RT)-PCR. Total RNA was extracted using the RNA SATA ${ }^{\mathrm{TM}}$ method (TEL-TEST B, Inc., Friendswood, TX) from PBMCs enriched in $\mathrm{T}$ cells from lupus or disease-control patients and normal volunteers. Two pairs of primers specific for human TCR $\zeta$ and $\beta$-actin were designed and synthesized according to their sequences $(10,11)$. The primers were as follows: TCR $\zeta$ chain, $5^{\prime}-$ CAAGATGAAGTGGAAGGCGC-3' and 5'-AATCCCCTGGGTGTTAGCGA-3'; and $\beta$-actin, 5'-CATGGGTCAGAAGGATTCCT-3' and 5'-AGCTCGTAGCTCTTCTCCAG-3'. Each primer (1 $\mu \mathrm{M})$ and $2.5 \mathrm{U}$ of AmpliTaq DNA polymerase (Perkin Elmer, Foster City, CA) in $80 \mu \mathrm{l}$ of PCR buffer containing $3 \mathrm{mM} \mathrm{MgCl}_{2}$ and $400 \mu \mathrm{M}$ dNTP were added to the RNA extract, and 30 PCR cycles were run at $95^{\circ} \mathrm{C}$ for $1 \mathrm{~min}$, then at $54^{\circ} \mathrm{C}$ for $1.5 \mathrm{~min}$, and finally at $72^{\circ} \mathrm{C}$ for $1.5 \mathrm{~min}$.

Northern blotting. $10 \mu \mathrm{g}$ of RNA from each sample was denatured, electrophoretically separated in 1\% agarose, $7 \%$ formaldehyde gels, and transferred onto nitrocellulose membranes. cDNA probes encoding for TCR $\zeta$ and $\beta$-actin were synthesized with RT-PCR and terminally labeled with $\left[\alpha-{ }^{32} \mathrm{P}\right] \mathrm{dCTP}(3,000 \mathrm{Ci} / \mathrm{mmol})$ (Amersham) to a specific activity of $2.5-5 \times 10^{-8} \mathrm{cpm} / \mu \mathrm{g}$ DNA. Hybridization (overnight at $42^{\circ} \mathrm{C}$ ) and exposure of the blots either to Kodak X-Omat film at $-70^{\circ} \mathrm{C}$ for $4 \mathrm{~d}$, or to a PhosphorImager screen for $2 \mathrm{~d}$ followed. The intensity of the bands was analyzed either densitometrically or with the help of a PhosphorImager (Molecular Dynamics, Sunnyvale, CA).

Statistical analysis. We used the unpaired Student's $t$ test and the Fisher exact test (STAT EXACT program; Cytel Corp., Cambridge,
MA) for statistical evaluation of our data. Values of $P \leq 0.05$ were considered significant.

\section{Results}

Increased TCR/CD3-initiated protein tyrosine phosphorylation in T cells from patients with SLE. T cell-enriched PBMCs from lupus patients, individuals with other systemic rheumatic diseases, or normal volunteers were treated with $10 \mu \mathrm{g} / \mathrm{ml}$ OKT3 isotypic control $\mathrm{mAb}$, or medium at $37^{\circ} \mathrm{C}$ for $1 \mathrm{~min}$. Whole cell lysates were obtained from unstimulated resting cells and at $1 \mathrm{~min}$ after stimulation as described previously (6). $20 \mu \mathrm{g}$ of protein from each lysate was separated electrophoretically on $10 \%$ polyacrylamide/SDS gels and analyzed for the overall amount of protein tyrosine phosphorylation. We did not observe the appearance of new bands in the lysates obtained from unstimulated cells from lupus patients. In addition, we did not record significant differences in the densitometric readings of the basal unstimulated levels of protein tyrosine phosphorylation bands between lupus patients and healthy volunteers $(P<0.8)$, lupus patients and disease-control patients $(P<0.7)$, or normal- and disease-control individuals $(P<0.9)$ (Fig. 1, $A$ and $B)$. However, after incubation with OKT3 for $1 \mathrm{~min}$, the intensity, determined by densitometry, of bands located between the 64- and the $36-\mathrm{kD}$ markers was obviously increased in $\mathrm{T}$ cells from 15 of the 21 SLE patients (71\%) when compared to the lysates of cells from normal individuals $(n=8)$ and from patients $(n=11)$ with other systemic rheumatic diseases (Fig. $1, C, D$, and $E$ ). The mean densitometric intensity of 1 min OKT3-stimulated cells was signifi-
A
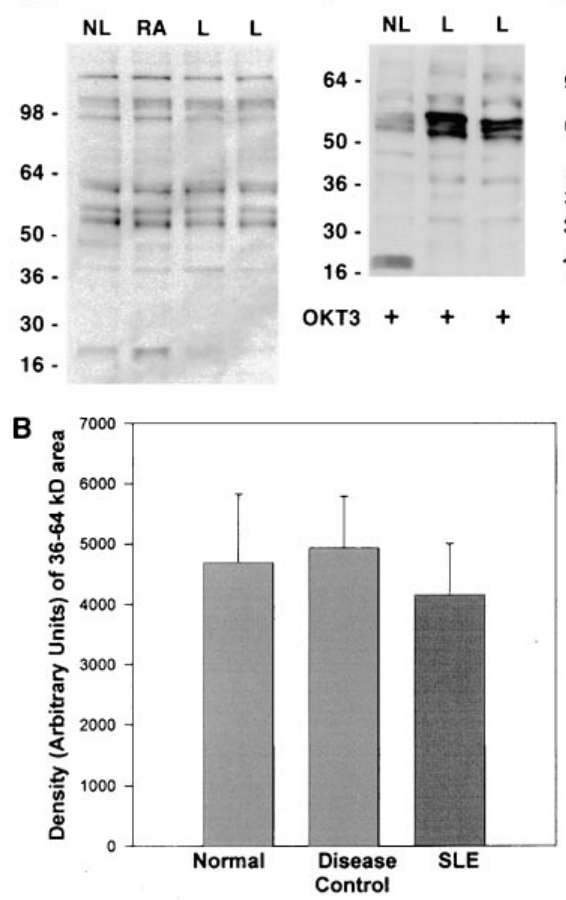

D
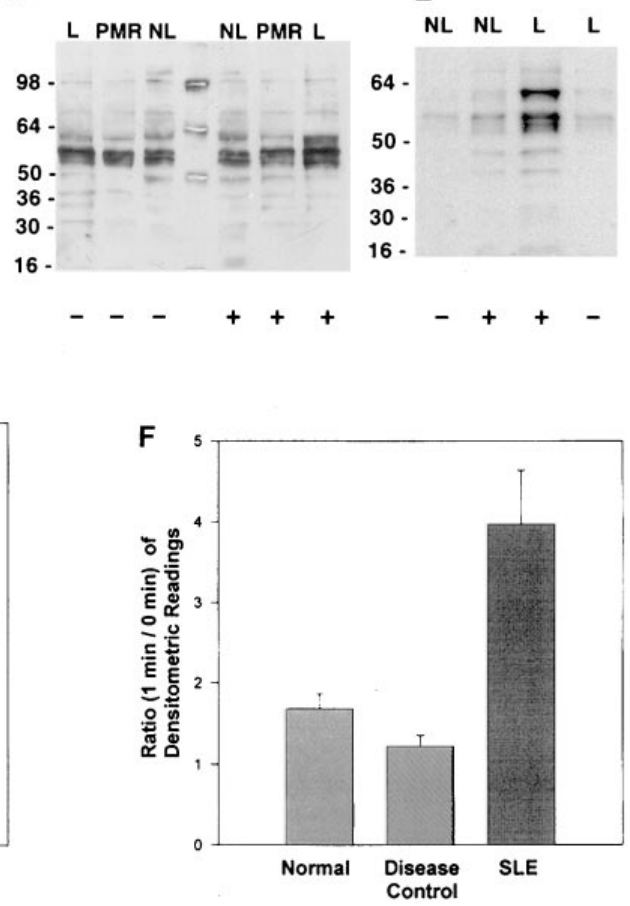

Figure 1. Increased TCR/CD3-mediated protein tyrosine phosphorylation in lupus $\mathrm{T}$ cells. Five million $\mathrm{T}$ cell-enriched PBMCs (>90\% $\mathrm{CD}^{+}$, by flow cytometry) from patients with SLE $(L)$, and other systemic rheumatic diseases and normal donors $(N L)$, were stimulated with $5 \mu \mathrm{g}$ OKT3 mAb (or left untreated, for unstimulated cells) for $1 \mathrm{~min}$ at $37^{\circ} \mathrm{C}$. Antiphosphotyrosine immunoblots were performed in electrophoretically separated equal amounts of protein $(20 \mu \mathrm{g})$ from total cell lysates. Four representative experiments are shown. $(A)$ Basal amounts of tyrosyl phosphorylated proteins from unstimulated cells from SLE patients, disease-, and normal-control individuals. (B) Densitometric measurements of the $36-64-\mathrm{kD}$ area (expressed in arbitrary units) in lysates obtained from resting cells from 21 SLE patients, 11 disease-control patients, and 8 healthy donors. $(C, D$, and $E$ ) Antiphosphotyrosine immunoblots of lysates from cells treated with OKT3 or isotypic control $\mathrm{mAb}$ for $1 \mathrm{~min}$ at $37^{\circ} \mathrm{C}$. $(F)$ Mean ratios \pm SEM of the densitometric readings of the 36-64-kD area measured in lysates from anti-CD3 mAb-stimulated (1 min) over the 36-64-kD area (densities obtained from resting cell lysates are collectively shown). The decrease or absence of a band located between the 16- and 30-kD markers in cell lysates obtained from either resting or OKT3-stimulated T cells from some patients with SLE should be noted. 
cantly higher in lysates of cells from SLE patients compared to cell lysates either from normal volunteers $(P<0.02)$ or from patients with other systemic rheumatic diseases $(P<0.015)$ and are collectively presented in Fig. $1 F$. Differences between normal volunteers and disease-control patients were not significant $(P<0.08)$. In some experiments we cross-linked the OKT3 mAb with a goat anti-mouse antiserum, but we did not notice any further enhancement of the phosphorylation pattern. Also, the use of an isotypic control murine mAb instead of OKT3 failed to induce protein tyrosyl phosphorylation above that observed with medium alone. We did not observe any correlation between the densitometric intensity of the bands with disease activity, specific clinical feature(s), or treatment status. These observations are highly similar to previously reported findings regarding the $\mathrm{Ag}$ receptor-initiated protein tyrosyl phosphorylation in lupus B cells in terms of band localization, disease specificity, and disease activity independence (6).

The time-response curve of the anti-CD3-mediated protein tyrosine phosphorylation is markedly altered in SLE patients. We conducted time course experiments to investigate whether the anti-CD3-mediated protein tyrosine phosphorylation in lupus $\mathrm{T}$ cells displayed a different pattern. We incubated lupus $(n=6)$ and normal $(n=3)$ T cells as described above for 1 and 2 min with OKT3. As shown in Fig. $2 A$, the densitometric intensity of the 36-64-kD area from OKT3-stimulated normal T cells was further increased at $2 \mathrm{~min}$. In contrast, the 2-min densitometric intensity of lysates from OKT3-stimulated lupus T
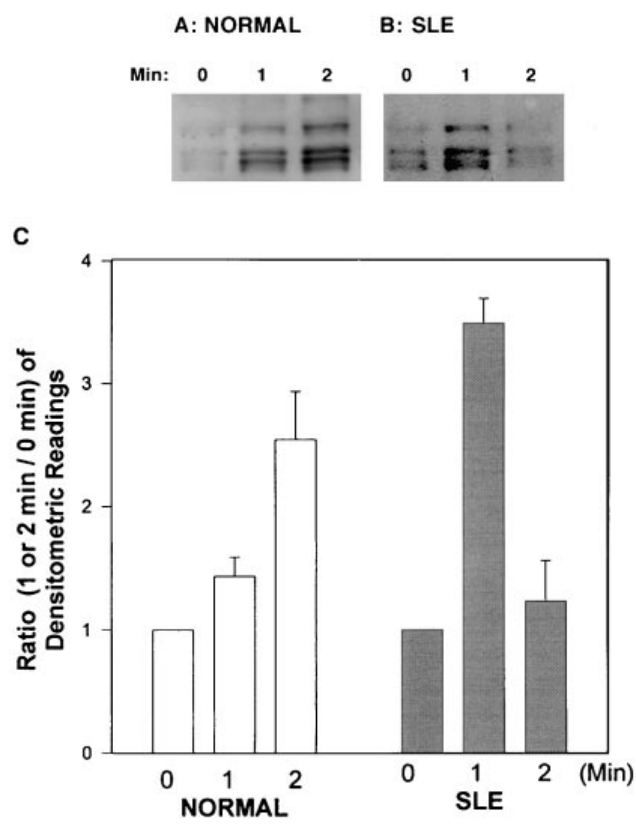

Figure 2. Time curve of the anti-CD3 mAb-mediated lupus T cell protein tyrosine phosphorylation. T cell-enriched PBMCs from normal donors and lupus patients were stimulated for 1 or 2 min with the OKT3 mAb. The electrophoretically separated cell lysate proteins were immunoblotted with the $4 \mathrm{G} 10$ antiphosphotyrosine mAb. Representative immunoblots from $\mathrm{T}$ cell lysates from $(A)$ one healthy volunteer and $(B)$ one SLE patient are shown. $(C)$ Mean $\pm \operatorname{SEM}(n=$ 3 for normals and 6 for SLE patients) ratios of the densitometric intensities of the $36-64-\mathrm{kD}$ area obtained for stimulated (1 or $2 \mathrm{~min}$ ) over the densities obtained from resting cells. cells was significantly lower than that detected for the first minute after stimulation (Fig. $2 \mathrm{~B}$ ). Interestingly, in two lupus patients (of six studied) the OKT3-induced protein tyrosine phosphorylation at $2 \mathrm{~min}$ was lower than that obtained before stimulation. The densitometric intensities of all the subjects studied are collectively presented in Fig. $2 C$. The difference of the means of the densitometric readings obtained at the 2-min time point between normal individuals and SLE patients were significant $(P<0.034)$.

Diminished expression of the TCR $\zeta$ chain in lupus patients using immunoblots, immunoprecipitations, and flow cytometry. In contrast to the increased tyrosyl phosphorylation pattern that was observed for the 36-64-kD area, the intensity of a band located between the 16- and 30-kD markers was significantly decreased (at all time points) in the cell lysates from 17 of 22 lupus patients $(77 \%)$ when compared to normal and disease-control individuals, and in some lysates from lupus patients the band was undetectable. The characteristics of this band, i.e., molecular size between 16 and $30 \mathrm{kD}$, tyrosyl phosphorylation in the resting state, and TCR/CD3-induced further tyrosyl phosphorylation (Fig. $3 \mathrm{~A}$ ), led us to consider the TCR $\zeta$ chain as a possible candidate. To investigate whether the TCR $\zeta$ protein in lupus $\mathrm{T}$ cells was in fact decreased or missing, or present but simply resistant to early tyrosyl phosphorylation, we conducted immunoblotting and immunoprecipitation experiments. T cell-enriched PBMC $\left(5 \times 10^{6}\right)$ from lupus patients, normal and disease-control individuals were lysed, and equal amounts of protein $(30 \mu \mathrm{g})$ were separated electrophoretically and analyzed for content of TCR $\zeta$ protein using two different anti- $\zeta$ antibodies. Using a murine anti-human $\mathrm{TCR} \zeta$ chain $\mathrm{mAb}$, no bands corresponding to the TCR $\zeta$ chain could be identified in 10 of 22 lupus patients studied, while the $\zeta$ protein was always present in cell lysates from normal $(n=$ 12) and 12 disease-control individuals (seven patients with RA, one with PMR, one with primary Sjögren's syndrome, one with Takayasu arteritis, one with osteoarthritis, and one with psoriatic arthritis) as shown in Fig. 3 B. Application of the Fisher's exact test $(2 \times 3$ table $)$ revealed a statistically significant difference $(P=0.001)$. We next used the polyclonal 387 anti-TCR $\zeta$ antibody to distinguish whether the whole protein or just a portion which includes the epitope detected by the murine 6B10.2 mAb (amino acids 36-54) was conformationally modified or missing. Immunoblots using the 387 antiserum showed that the $\zeta$ chain protein was again either obviously decreased or undetectable in 6 of 9 SLE patients examined, when compared to the disease-control patients $(n=7)$ and normal individuals $(n=4)$, where it was always present in comparable amounts. One representative immunoblot using the rabbit 387 antiserum (one patient with SLE and two different patients with RA) is shown in Fig. $3 C$. To further document our findings, $500 \mu \mathrm{g}$ of total protein from lysates obtained from three SLE patients, one normal and two disease-control individuals, was immunoprecipitated using the 387 rabbit anti-human TCR $\zeta$ antibody, and subsequently the TCR $\zeta$ chain was detected in immunoblots using the murine 6B10.2 mAb. Preliminary experiments showed that both these antibodies could detect not only the unphosphorylated, but the phosphorylated form(s) of TCR $\zeta$ as well (data not shown). The TCR $\zeta$ chain could be immunoprecipitated from the cell lysates obtained from normal and disease-control individuals. In the lysates from three SLE patients (Fig. $3 \mathrm{D}$ ), the immunoprecipitable amounts of TCR $\zeta$ were decreased in one, comparable to nor- 
IB: Anti-phosphotyrosine

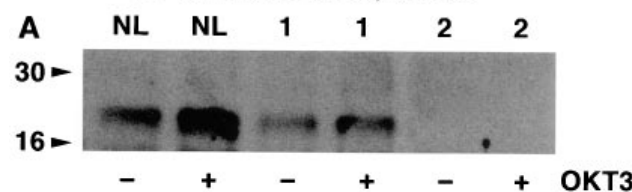

B

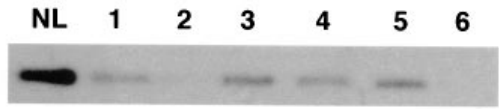

IB: Murine anti-TCR zeta mAb

C

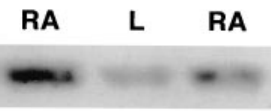

IB: Rabbit anti-TCR zeta Ab

D

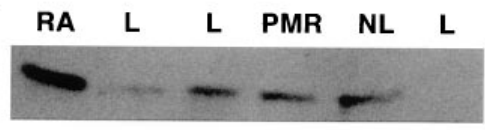

IP: Rabbit anti-TCR zeta $A b$

IB: Murine anti-TCR zeta mAb mal in another, and undetectable in a third patient. In lupus patients displaying absence of the full-length $\zeta$ chain, there was no other product with a smaller size (indicative of possible cleavage) detected further down in our gels.

To further establish the deficiency (or absence) of the $\mathrm{TCR} \zeta$ chain in whole lupus $\mathrm{T}$ cells and to characterize its expression in T cell subsets, we conducted flow cytometry experiments. Digitonin-permeabilized cells were incubated with the

Figure 3. Deficient TCR $\zeta$ protein expression in lysates from $\mathrm{T}$ cells of SLE patients. Five million resting T cell-enriched PBMCs from lupus patients, disease-control patients, and normal volunteers were lysed and an equal amount of protein $(30 \mu \mathrm{g})$ from these whole-cell lysates was analyzed electrophoretically, transferred to nitrocellulose membranes, and then immunoblotted either with $(A)$ the $4 \mathrm{G} 10$ antiphosphotyrosine $\mathrm{mAb},(B)$ the murine $6 \mathrm{~B} 10.2$ anti-human TCR $\zeta \mathrm{mAb}$, or (C) the 387 rabbit anti-human TCR $\zeta$ polyclonal antibody. $(D) \mathrm{T}$ cellenriched PBMC lysate protein $(500 \mu \mathrm{g})$ from normal $(N L)$, lupus $(L)$, RA, and PMR patients was immunoprecipitated with the 387 antibody and the amount of $\zeta$ chain was detected by immunoblotting with the $6 \mathrm{~B} 10.2 \mathrm{mAb}$.
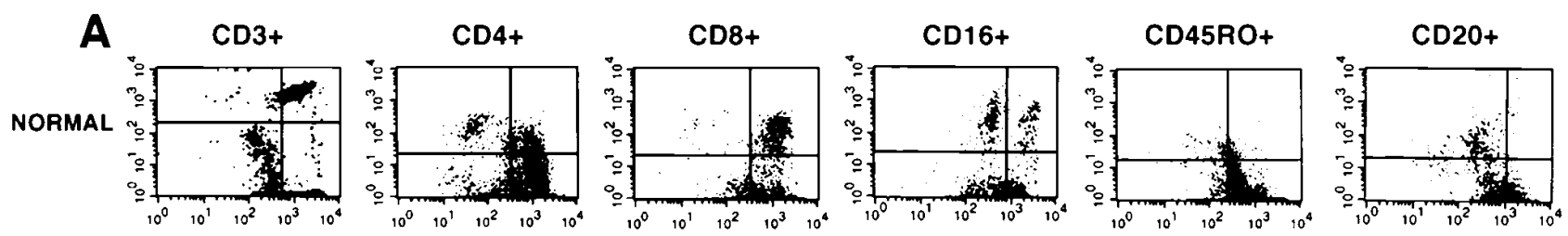

LUPUS
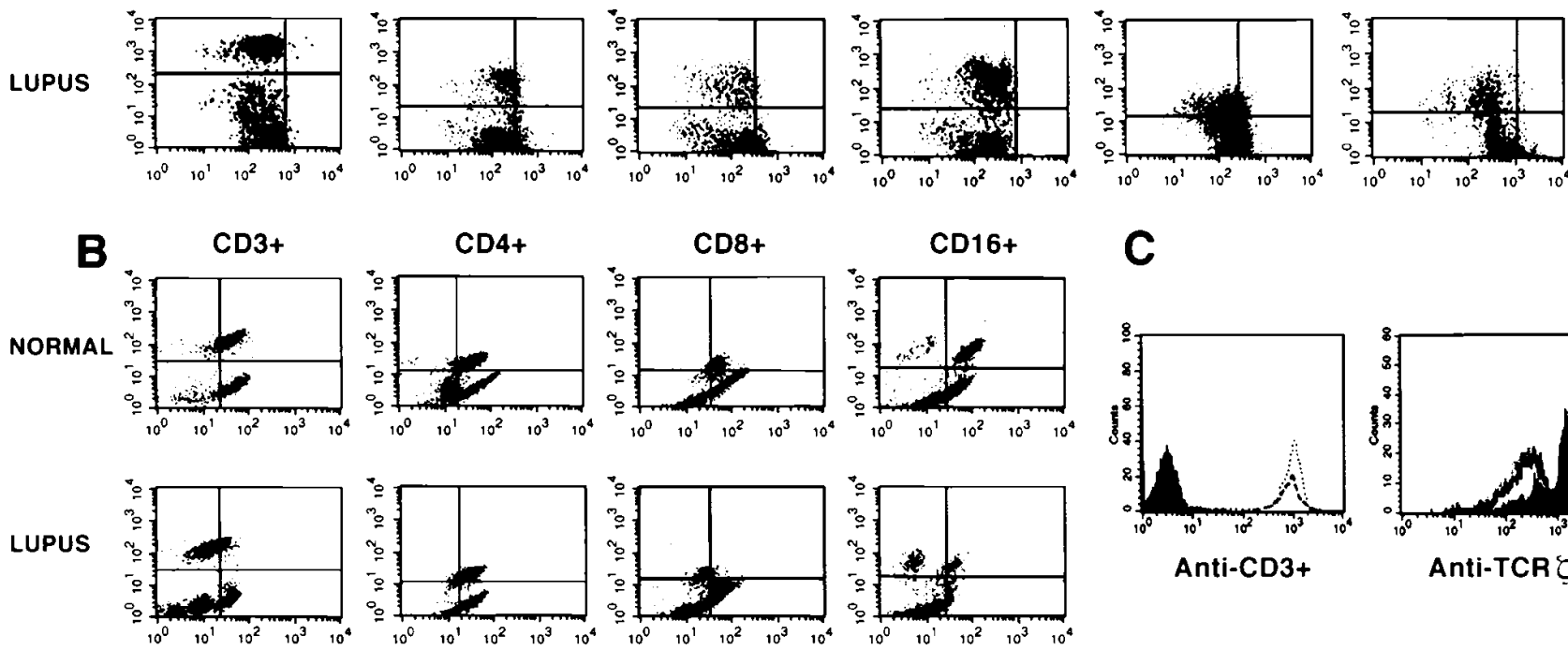

C

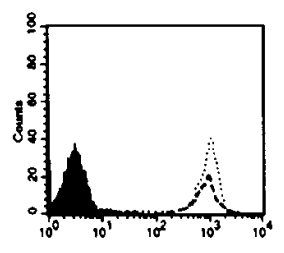

Anti-CD3+

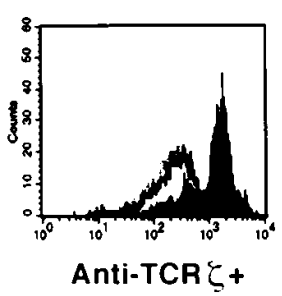

Figure 4. Detection of the TCR $\zeta$ chain in T cells from patients with SLE using flow cytometry. Patients with undetectable $\zeta$ chain in immunoblots were also $\zeta$ chain negative by flow cytometric analysis of digitonin-permeabilized PBMCs. Cells were indirectly stained for TCR $\zeta$ chain expression using a murine anti- $\zeta \mathrm{mAb}$ and FITC-conjugated goat anti-mouse antibody $\left(x\right.$ axis). Double staining was performed for $\mathrm{CD}^{+}, \mathrm{CD}^{+}$, $\mathrm{CD}^{+}, \mathrm{CD} 45 \mathrm{RO}^{+}$, and $\mathrm{CD} 16^{+}$cells using PE-conjugated $\mathrm{mAbs}$ ( $y$ axis). $\mathrm{CD} 20^{+}$cells (B cells) were also stained as negative control cells and as indicators of efficient Fc blockade (analyzed in Methods). A representative experiment of a TCR $\zeta^{-}$lupus patient and a normal volunteer is shown $A$. All $\zeta$-bearing cell populations clearly stained positively for the normal donor and negatively in the patient with SLE. Another patient with decreased expression of TCR $\zeta$ in immunoblots is shown in $B$. While the $\mathrm{CD}^{+}$cells are largely unaffected and not obviously different than the respective normal control, the $\mathrm{CD}^{+}$and $\mathrm{CD} 16^{+}$cells were predominantly $\mathrm{TCR} \zeta$ negative. The histograms in $C$ represent staining with anti$\mathrm{CD} 3 \epsilon$ and TCR $\zeta$ of a $\zeta$-negative lupus patient and a healthy individual. Expression of the CD $3 \epsilon$ chain (left) was similar in the normal and the lupus individuals (dotted lines). Negative control is shown as the shadowed histogram. Expression of the $\zeta$ chain (right) for the lupus patient (dotted line) is similar to that of the negative control (solid line) in the $\zeta$-negative lupus patient. TCR $\zeta$ chain expression in the normal donor is shown as the shadowed histogram. 


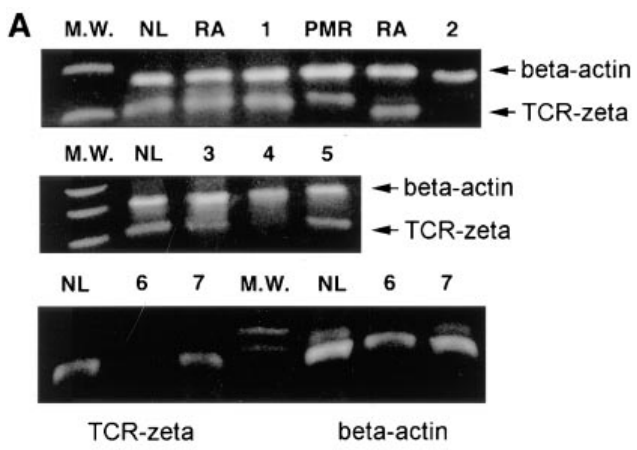

B

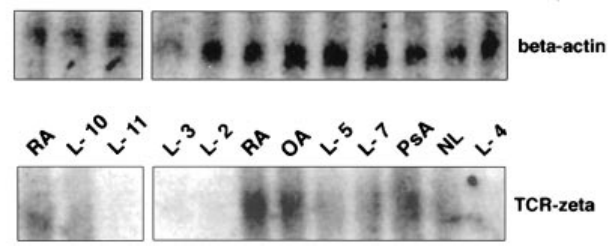

Figure 5. Detection of TCR $\zeta$ chain mRNA. RT-PCR $(A)$. Two primers were constructed for the $\zeta$ chain and the products were analyzed electrophoretically in $1 \%$ agarose gels prepared with Tris-borate EDTA buffer, stained with $20 \mu \mathrm{g}$ ethidium bromide, and photographed. The mRNA of a housekeeping gene ( $\beta$-actin) was always used as an internal control. Three representative experiments are shown here, including seven different patients with SLE (lanes 1-7), three different normal donors $(N L)$, two different RA patients, and one with PMR. Northern blot analysis of TCR $\zeta$ mRNA and $\beta$-actin mRNA was used as an internal control (as described in Methods) from different lupus patients $(L-2,-4,-5,-7,-10$, and -11$)$, disease controls (RA,PMR, osteoarthritis $[O A]$, and psoriatic arthritis $[P s A])$, and normal controls $(N L)$ are shown in $B$.

6B10.2 mAb, followed by FITC-conjugated goat anti-mouse $\mathrm{Ab}$, and PE-conjugated anti-CD3, anti-CD4, anti-CD8, antiCD45RO, and anti-CD16 antibodies as described in Methods. Cells bearing Fc receptors but not TCR $\zeta$ were also PE stained (anti-CD14, anti-CD20, or both) as negative control cells. The relevant isotypic control $\mathrm{mAb}$ was also always used. We studied PBMCs from nine patients with SLE and six normal control individuals. Immunoblot-established total absence of $\mathrm{TCR} \zeta$ was associated with complete lack of staining of $\mathrm{CD}^{+}$, $\mathrm{CD}^{+}, \mathrm{CD}^{+}, \mathrm{CD} 45 \mathrm{RO}^{+}$, and $\mathrm{NK}\left(\mathrm{CD} 16^{+}\right)$cells with the antiTCR $\zeta$ antibody (Fig. $4 A$ ). Decreased expression of TCR $\zeta$, established by immunoblotting, correlated with reductions of $\zeta^{+}$ $\mathrm{CD}^{+}$, and NK $\left(\mathrm{CD} 16^{+}\right)$cells. When T cell subsets were examined separately, $\mathrm{CD} 8^{+} \mathrm{T}$ cells lacked $\mathrm{TCR} \zeta$ chain expression to a greater extent than $\mathrm{CD}^{+}$cells (Fig. $4 \mathrm{~B}$ ). Finally, $\mathrm{T}$ cells from patients with SLE who expressed normal amounts of TCR $\zeta$ by immunoblotting displayed percentages of $\mathrm{TCR} \zeta^{+}$ cells (and subsets) that were comparable to those of normals (not shown). The expression of the $\epsilon$ chain of the CD3 marker was unaffected by the presence or absence of the TCR $\zeta$ chain, and was found to be similar to that of the controls as shown in Fig. $4 C$, reconfirming previously reported data (5). The above immunoblotting and immunoprecipitation experiments, as well as the flow cytometric staining experiments clearly show that the TCR $\zeta$ chain protein is quantitatively decreased or absent in $\mathrm{T}$ cells from patients with SLE in a disease-specific fashion.

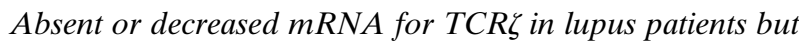
not in control individuals. The TCR $\zeta$ chain can be selectively degraded upon $\mathrm{T}$ cell activation (12) or in other conditions by posttranslational processes which are incompletely understood $(13,14)$. To investigate whether the decreased amounts of $\mathrm{TCR} \zeta$ chain detected in lupus T cells was the result of posttranslational degradation, or the outcome of abnormalities at the mRNA level, we extracted total RNA from PBMCs enriched in T cells and conducted RT-PCR using oligomer primers (described in Methods) that amplify the full-length mRNA of the TCR $\zeta$ chain. Results (Fig. $5 A$ ) obtained for eight lupus patients revealed that in three patients there was no detectable full-length mRNA band for the TCR $\zeta$, while this band was always present in the PBMC extracts from disease-control patients $(n=6$ in total, [three RA patients, one with PMR, one with Sjögren's syndrome, and one with Takayasu's arteritis]) and in all normal individuals $(n=3)$. An internal control corresponding to the mRNA of a house keeping gene ( $\beta$-actin) was always included and detected. Northern blots performed for the same controls and patients showed that of the eight SLE patients studied, the TCR $\zeta$ mRNA was undetectable in three, decreased but detectable in three, and no different than normal in two patients as shown in Fig. 5 B. Northern blot quantitative analysis of the TCR $\zeta$ (when present) and $\beta$-actin mRNA was performed either densitometrically or with the use of a PhosphorImager. Application of the Fisher's exact test $(3 \times 2$ table $)$ revealed a statistically significant difference $(P<$ $0.0023)$.

Associations of TCR $\zeta$ chain deficiency with early and late TCR/CD3-mediated T cell functions. The $\zeta$ chain of the TCR is a molecule involved in the TCR/CD3-initiated signal transduction biochemistry. To assess the consequences of TCR $\zeta$ deficiency, we studied the anti-CD3-induced changes in $\left[\mathrm{Ca}^{2+}\right]_{i}$ (an early event in the signal transduction pathway), and the anti-CD3-induced cell proliferation (a late event).

The OKT3-induced (after cross-linking by goat anti-mouse antibody) peak $\left[\mathrm{Ca}^{2+}\right]_{\mathrm{i}}$ ratios were studied in negatively selected and Indo-1-loaded T cells from eight patients with SLE (four were $\mathrm{TCR} \zeta^{+}$and four were $\mathrm{TCR} \zeta^{-}$as determined by Western immunoblots) and were compared to the responses of $\mathrm{T}$ cells obtained from four normal individuals (normal controls) as described previously (5). Baseline values of $\left[\mathrm{Ca}^{2+}\right]_{\mathrm{i}}$ ratios were comparable for unstimulated $\mathrm{T}$ cells from lupus patients and from normal volunteers. All eight lupus patients responded in a supraphysiological manner, which is in agreement with previously published data (5). Analysis of the $\left[\mathrm{Ca}^{2+}\right]_{i}$ responses according to the presence or absence of TCR $\zeta$ yielded significant differences. Specifically, absence of TCR $\zeta$ was associated with $\left[\mathrm{Ca}^{2+}\right]_{\mathrm{i}}$ responses which were higher than normal (peak ratio of $\left[\mathrm{Ca}^{2+}\right]_{\mathrm{i}}: 16.1 \pm 0.65$ vs. $14.1 \pm 0.26$, $P<0.026)$, but were significantly lower than the $\left[\mathrm{Ca}^{2+}\right]_{\mathrm{i}}$ responses of patients who were $\mathrm{TCR} \zeta^{+}(16.1 \pm 0.65$ vs. $19.2 \pm 0.71$, $P<0.019)$ and were characterized as low supranormal. Patients who were $\mathrm{TCR} \zeta^{+}$responded in a high supranormal manner. Their responses were significantly higher both from the TCR $\zeta^{-}$patients $(P<0.019)$ and from the normal controls $(P<0.0005)$. Thus, it is clear that SLE patients display higher than normal $\left[\mathrm{Ca}^{2+}\right]_{\mathrm{i}}$ responses and that they could be stratified as high or low hyperresponders according to the presence or absence of the TCR $\zeta$ chain (Fig. $6 A$ ).

We also studied the OKT3-induced proliferation profile of TCR $\zeta$ positive and negative SLE patients. For the prolifera- 

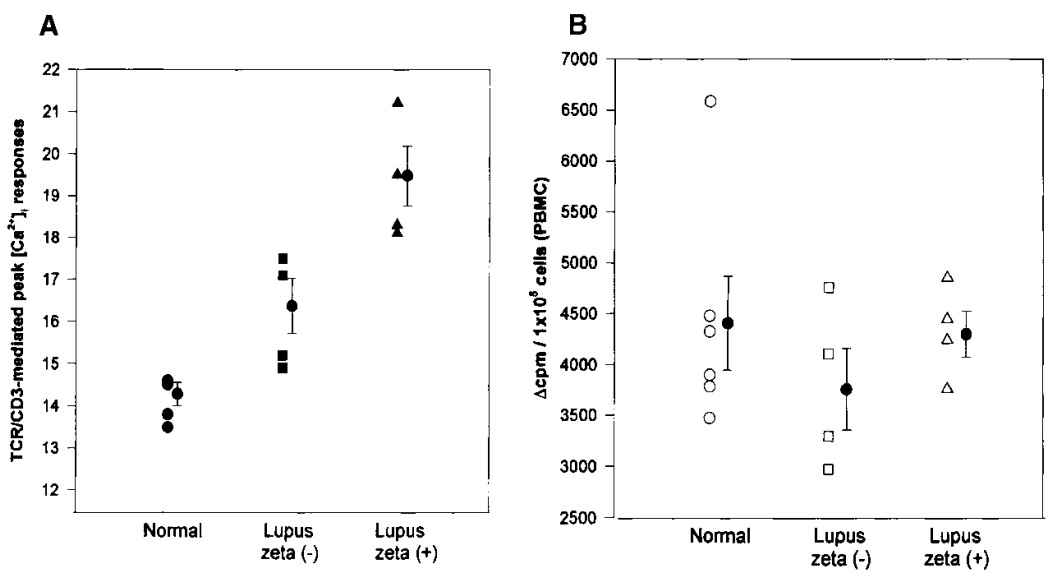

Figure 6. Early and late anti-CD3-mediated signaling events in the absence or presence of the TCR $\zeta$ chain in lupus T cells. $(A)$ Measurement of TCR/CD3-initiated $\left[\mathrm{Ca}^{2+}\right]_{i}$ responses of negatively selected, Indo1-loaded fresh peripheral $\mathrm{T}$ cells. The magnitude of the peak $\left[\mathrm{Ca}^{2+}\right]_{\mathrm{i}}$ responses was determined flow cytometrically in four normal donors and eight patients with SLE (four were TCR $\zeta^{-}[-]$and four were $\left.\operatorname{TCR} \zeta^{+}[+]\right)$and are represented here as the 381:525 $\mathrm{nm}$ fluorometric ratio, which is directly proportional to the $\left[\mathrm{Ca}^{2+}\right]_{\mathrm{i}}$. The presence or absence of TCR $\zeta$ could clearly stratify the lupus patients as high or low responders, respectively. All lupus patients tested displayed supranormal $\mathrm{Ca}^{2+}$ fluxes. Differences between the three groups shown here were always significant. The anti-CD3-mediated proliferative responses (a late signaling event) of six normal donors and eight

lupus patients are shown in $B$. The proliferative responses of TCR $\zeta^{+}$and TCR $\zeta^{-}$patients with SLE were not significantly different than the responses of the control individuals. Bars represent mean \pm SEM.

tion assays PBMCs were used. To obtain comparable results, the percentage of $\mathrm{CD}^{+}$cells was determined previously by flow cytometry, and only those patients and controls with similar $\mathrm{CD}^{+}$subpopulations were used. Time- and dose-response experiments determined the optimal OKT3 dose and incubation time $(10 \mu \mathrm{g} / \mathrm{ml} \mathrm{OKT3}$, and incubation for $3 \mathrm{~d})$. Eight patients with SLE and six normal volunteers were studied. The proliferative responses of PBMCs obtained from normal subjects were not different from the responses of lupus patients who were $\mathrm{TCR} \zeta^{+}(P=0.35)$ or $\mathrm{TCR} \zeta^{-}(P=0.87)$. The difference in the responses between $\mathrm{TCR} \zeta^{+}$and $\mathrm{TCR} \zeta^{-}$patients was, similarly, not statistically significant $(P=0.28)$ (Fig. $6 B$ ).

The increased TCR/CD3-induced protein tyrosine phosphorylation and the absence of TCR $\zeta$ in $T$ cells from the same SLE patients persist over time despite changes in disease activity. Even though the pattern of TCR/CD3-mediated early protein tyrosine phosphorylation was found to be independent of disease activity, one could still argue that this aberration may correlate, in an individual SLE patient, with changes in disease activity, and/or the appearance or disappearance of specific clinical manifestations. To address this question, four unselected lupus patients were restudied 3-9 mo after their initial evaluation. In all four patients the SLEDAI had changed. Nevertheless, the increased Ag receptor-mediated overall protein tyrosine phosphorylation at $1 \mathrm{~min}$ did not parallel changes in disease activity. Patients $\mathrm{A}$ and $\mathrm{D}$ had significant changes in their disease activity (a decrease of $75 \%$ and an increase of $172 \%$, respectively, in their SLEDAI) while the densitometrically measured ratio (1:0 min) of tyrosine phosphorylation was not substantially altered. On the other hand, for patients $\mathrm{B}$ and $\mathrm{C}$, who displayed no major changes in their SLEDAI, the ratio (1:0 min) was substantially either increased or decreased, respectively (Fig. 7). These experiments further confirm that the anti-CD3 mAb-induced early overall protein tyrosine phosphorylation pattern does not correlate with changes in disease activity, thus, implying a permanent intrinsic defect in the early Ag receptor-initiated signaling machinery. Importantly, patient $\mathrm{D}$ had detectable and patients $\mathrm{A}, \mathrm{B}$, and $\mathrm{C}$ had undetectable bands corresponding to the TCR $\zeta$ chain as determined by Western immunoblotting in both evaluations. Also, lack of TCR $\zeta$ chain expression found by Western immunoblots during the first visit was in agreement with the results of flow cytometric $\mathrm{TCR} \zeta$ chain detection in perme- abilized cells during a later (after 12-14 mo) visit. These data imply that the pattern of $\zeta$ chain expression is time- and disease activity-independent.

Patients with SLE are usually receiving treatment with agents which alter the function of the immune system. To exclude a potential drug effect on the TCR $\zeta$ chain deficiency, our lupus patients were analyzed in comparison with RA patients from our disease-control group who suffered from systemic autoimmune rheumatic diseases and received similar agents. As depicted in Table I, the $\zeta$ chain deficiency in patients with SLE cannot be attributed to a drug effect.

\section{Discussion}

We conducted this study to investigate possible aberrations in the early events of the signal transduction pathway in lupus $\mathrm{T}$ cells. Since disease-specific abnormalities in the TCR/CD3mediated $\left[\mathrm{Ca}^{2+}\right]_{\mathrm{i}}$ responses have been demonstrated already
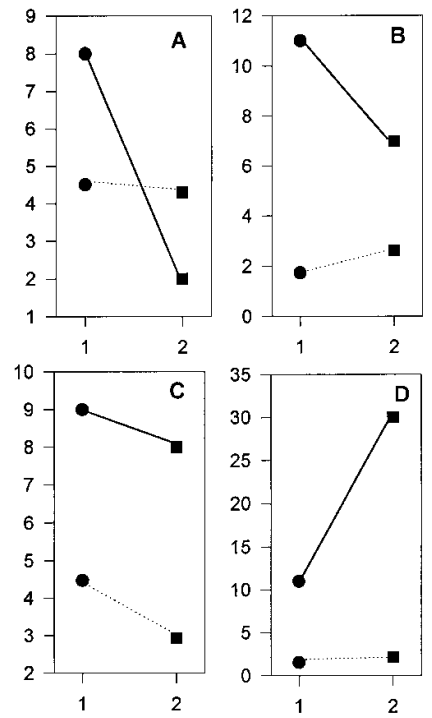

Figure 7. The increased protein tyrosine phosphorylation pattern in lupus patients does not correlate with disease activity. Four unselected $(A, B$, $C$, and $D$ ) patients with SLE were restudied 3-9 mo after the initial evaluation. In all four patients, the SLEDAI (solid lines) had changed. Antiphosphotyrosine immunoblots were performed on reevaluation. Induction of tyrosyl phosphorylation was calculated as the ratio of the densitometric measurements of the bands included in the $36-64-\mathrm{kD}$ area obtained after 1 min of OKT3mediated stimulation, over the values obtained for the same area in cell lysates from unstimulated resting cells (dotted

lines). Circles represent the values of the SLEDAI or of the ratios during the first evaluation, and squares represent the SLEDAI or the tyrosine phosphorylation induction ratios obtained on reexamination. 
Table I. Expression of the TCR $\zeta$ Chain in T Cells from

Patients with SLE and RA Who Were Treated with

Immunosuppressive Agents

\begin{tabular}{lcc}
\hline \multicolumn{1}{c}{ Patients $(n)$} & TCR $\zeta$ chain $(+)$ & TCR $\zeta$ chain $(-)$ \\
\hline SLE patients on prednisone (14) & 8 & 6 \\
RA patients on prednisone (4) & 4 & 0 \\
SLE patients on cytotoxics* (6) & 3 & 3 \\
RA patients on cytotoxics $^{\ddagger}(7)$ & 7 & 0 \\
\hline
\end{tabular}

*Four were on azathioprine, one was on cyclophosphamide, and one was on methotrexate. ${ }^{\ddagger}$ All seven were on methotrexate.

(5), we explored biochemical events which precede the Ag receptor-induced $\mathrm{Ca}^{2+}$ fluxes. The earliest known events in the $\mathrm{Ag}$ receptor-initiated signaling is the activation of the src and the ZAP-70/Syk family of PTKs, that results in reversible tyrosyl phosphorylation of multiple protein substrates (2), the majority of which remain unknown. We used the OKT3 mAb to trigger the signaling cascade, and we evaluated the pattern of early tyrosine phosphorylation in primary $\mathrm{T}$ cells from patients with SLE, patients with other systemic rheumatic diseases, and normal individuals.

Although no additional bands (corresponding to tyrosyl phosphorylated proteins) were noted in the antiphosphotyrosine immunoblots of lysates of unstimulated T cells from patients with SLE, lysates from OKT3-stimulated lupus T cells, but not from disease-control or normal-control $\mathrm{T}$ cells, displayed altered quantitative and time course responses. Specifically, at the first minute of treatment with anti-CD3 mAb, the intensity of bands with apparent molecular sizes between 64 and $36 \mathrm{kD}$ was significantly enhanced in lupus $\mathrm{T}$ cells compared to control individuals, in a disease-specific and disease activity-unrelated mode. This abnormality persisted in four patients who were reevaluated after several months, when disease activity and clinical manifestations had changed. While normal $\mathrm{T}$ cells exhibit gradually rising levels of protein tyrosine phosphorylation over a 2-min period in a near-linear mode, the lupus $\mathrm{T}$ cells respond to the same OKT3-induced stimulus in a burst-like fashion, achieving supranormal amounts of tyrosyl phosphorylated cellular proteins quite early (by the first minute) and return to a close-to-resting state by the second minute.

This earlier and higher than normal response of $\mathrm{T}$ cells from SLE patients is in agreement with the earlier and higher than normal $\mathrm{Ca}^{2+}$ fluxes which follow TCR/CD3 ligation (5). Our current data are also similar to those obtained from the study of Ag receptor-initiated early signaling events in lupus B cells (6), suggesting a possibly unifying pathology in the signal transduction of SLE lymphocytes. In a previously published study investigating the induction of tyrosyl phosphorylated proteins after anti-CD3 mAb cross-linking, T cells from SLE patients were reportedly refractory to stimulation compared to $\mathrm{T}$ cells from normal donors (15). Nevertheless, this anti-CD3 antibody effect was studied at a relatively late point $(3 \mathrm{~min})$, and earlier points were omitted. In our study we show that even earlier (at $2 \mathrm{~min}$ ) the lupus $\mathrm{T}$ cells have produced a fast supraphysiological response, and have already returned to a close-to-resting state.

In contrast to the obvious and consistent OKT3-induced hyperphosphorylation of proteins of $36-64 \mathrm{kD}$, we noticed that a band located between 16 and $30 \mathrm{kD}$, which was consistently present in lysates from normal $\mathrm{T}$ cells, was frequently decreased in the antiphosphotyrosine immunoblots of lupus $\mathrm{T}$ cells. This substrate (when present) displayed decreased intensity in the resting state, but it was undergoing tyrosyl phosphorylation after stimulation with OKT3. Immunoblotting and immunoprecipitation experiments identified this protein to be the TCR $\zeta$ chain. The possibility of detecting only one epitope (linear or conformational) of this protein was largely eliminated by using two different (a murine monoclonal and a rabbit polyclonal) antibodies. The expression of the $\zeta$ chain was either deficient or diminished in $77 \%$ of the studied SLE patient population, while it was always sufficiently present in all normal donors and patients with other systemic rheumatic diseases that were also studied. Further confirmation of the $\mathrm{TCR} \zeta$ chain deficiency was provided by flow cytometry experiments of digitonin-permeabilized cells. The TCR $\zeta$ chain deficiency in lupus $\mathrm{T}$ cells can be considered chain-specific, since our data (and a previously reported study) did not find differences in the expression of CD $3 \epsilon$ polypeptide on lupus T cells, regardless of the presence or absence of the $\zeta$ chain (5). TCR $\zeta$ was absent from cell subsets $\left(\mathrm{CD}^{+}, \mathrm{CD}^{+}, \mathrm{CD}^{+}, \mathrm{CD}^{4} 5 \mathrm{RO}^{+}\right.$, and $\mathrm{CD} 16^{+}$) from patients who lacked the TCR $\zeta$ chain by immunoblotting. For those patients with obviously normal TCR $\zeta$ expression, no difference in all subsets could be detected by flow cytometry. In patients who had decreased TCR $\zeta$ expression, the $\mathrm{CD} 4^{+}$cells were not obviously affected, while the $\mathrm{CD} 8^{+}$and $\mathrm{CD}_{16}{ }^{+}$cell subsets were, to a greater extent, $\zeta$ chain deficient. This relatively selective involvement has been previously described in $\zeta$-knockout mice $(16,17)$ where the $\mathrm{CD}^{+} \mathrm{T}$ cell subset was more severely affected by the absence of the $\zeta$ polypeptide as compared to the $\mathrm{CD}^{+}$subset. Functionally, this defect may contribute to the multiplicity of immune cell abnormalities which predominantly involve $\mathrm{CD}^{+}$and NK cells in lupus.

Selective degradation of a previously expressed TCR $\zeta$ after T cell activation has also been reported (12), as well as the lack of TCR $\zeta$ chain in tumor-infiltrating lymphocytes $(13,14)$ under the influence of poorly understood (but reversible) posttranslational mechanisms. In the latter case, FceRI $\gamma$ may substitute for the missing $\mathrm{TCR} \zeta$. The absence or diminished expression in T cells from some SLE patients reported herein is not the result of posttranslational modifications since, in lupus patients, the mRNA for the TCR $\zeta$ was undetectable or severely decreased either by Northern blots or (more importantly) by RT-PCR. None of the normal or the disease-control individuals studied displayed a similar abnormality.

The TCR $\zeta$ forms a homodimer which is part of the TCR/ CD3 complex. Different functions have been attributed to the $\zeta$ chain including roles in signaling in mature T cells, in proper assembly and transfer from the cytoplasm to the cell surface of the complete TCR/CD3 heterooligomer, and in normal development and selection of immature thymocytes (16-18). The long cytoplasmic domain of each $\zeta$ chain contains three ITAM modules which participate in signaling. After these ITAMs become tyrosyl phosphorylated (by members of the src family of PTK), they form anchoring sites for the tandem SH2-domains of ZAP-70, a PTK important for further signal propagation (19). Data originating from the study of transformed T cells suggest that in the resting state the TCR $\zeta$ is found in a nonphosphorylated form and becomes rapidly phosphorylated after TCR/CD3 ligation. This is not true for the normal peripheral T cells, where TCR $\zeta$ is constantly phosphorylated (increasing 
further after TCR/CD3 ligation) and ZAP-70 is constantly bound on it (20). In a minority of T cells $(5-10 \%)$, the $\zeta$ chain may be found as part of a heterodimer with the highly homologous TCR $\eta$ chain (with no known physiological role), which is an alternatively spliced product of the $\zeta$ gene (21) and has two ITAMs. There are T cell subsets which normally do not contain any TCR $\zeta$ and its place is taken by another homologous protein, the $\gamma$ chain of the high-affinity receptor type I for the Fc fragment of $\operatorname{IgE}($ Fce RI $\gamma)$ (22-24), which contains a single ITAM. Fc $\in$ RI $\gamma$ has also been identified as a signal transducing molecule in receptors for the Fc fragment of IgG as well (25), where TCR $\zeta$ can also be found $(26,27)$.

To assess the functional consequences of TCR $\zeta$ deficiency in lupus $\mathrm{T}$ cells we studied the anti-CD3-induced $\left[\mathrm{Ca}^{2+}\right]_{\mathrm{i}}$ responses and the anti-CD3-induced proliferation in comparison with $\mathrm{T}$ cells from healthy volunteers. TCR $\zeta$ status significantly affected the $\left[\mathrm{Ca}^{2+}\right]_{\mathrm{i}}$ responses. The constantly supraphysiological OKT3-induced $\left[\mathrm{Ca}^{2+}\right]_{\mathrm{i}}$ responses of lupus T cells could be clearly stratified as high or low supranormal in correlation with the presence or absence of the TCR $\zeta$ chain. While this early signal transduction event was clearly correlated to the $\zeta$ chain status, the same was not true for the OKT3-induced cell proliferation. This late event was not affected by the $\zeta$ chain status. The AgR-mediated proliferative behavior of lupus $\mathrm{T}$ cells is unclear, with different groups reporting different results (for review see reference 28). It is possible that other mediators participating in this relatively late cellular function may overcome or compensate for the absence of the $\zeta$ chain. Also, the sensitivity of this method may not allow for the detection of differences in the two patient groups. Other indicators of cellular activation may be more sensitive to the $\zeta$ chain defect, an issue which further studies should address.

The TCR $\zeta$ chain is important for the proper assembly and transfer to the cell membrane of the whole TCR/CD3 complex. Experiments in $\zeta$-knockout mice have shown that the development of mature T cells and the expression of the TCR $\alpha / \beta$ complex on the surface of such $\mathrm{T}$ cells are greatly impaired. Nevertheless, the expression of TCR $\zeta$ is not an absolute requirement for proper development of T cells. Mature singlepositive TCR $\alpha / \beta$ cells appear in the periphery of $\zeta$-knockout mice, and the development and function of non-TCR $\alpha / \beta$ cells is totally unaffected. Moreover, even when small (ITAM-less) fragments of the $\zeta$ chain are expressed only, instead of the fulllength chain, functional TCR/CD3 complexes are sufficiently expressed on the cell surface. It was recently reported that $\zeta$-knockout mice transfected with the FceRI $\gamma$ gene have normal T cell development and function (29). In murine knockout models that express neither TCR $\zeta$, nor TCR $\eta$ and Fc $\epsilon$ RI $\gamma$, mature $\mathrm{T}$ cells were still produced (for review see reference 30). The above data imply that the TCR $\zeta$ chain may not be absolutely required either for the signal transduction cascade initiated by the TCR/CD3 complex in mature or immature T cells, or for the proper assembly and transfer to the surface of the TCR/CD3 polypeptides. Thus, TCR $\zeta$-deficient T cells can initiate and propagate the signal transduction cascade, provided that they express on their cell surface sufficient amounts of TCR/CD3. In such a situation, signaling can be transduced by using the ITAMs of the other invariant chains of the CD3 complex $(31,32)$. In fact, signal transducing molecules such as ZAP-70 have been shown to functionally bind to these non- $\zeta$ ITAMs (33). It has also been reported that Syk instead of ZAP-70 is alternatively and preferentially recruited to the polypeptide (if any) which may substitute for the missing TCR $\zeta$ chain (i.e., the FceRI $\gamma$ ) and propagates the generated signals further downstream (34). Even though Ag receptor signaling takes place in the absence of $\zeta$, the outcome is different. The pattern of protein tyrosyl phosphorylation which is observed under such settings is altered, and the production of IL-2 is decreased (31). This outcome is similar to the presently described abnormal pattern of OKT3-mediated tyrosine phosphorylations in lupus T cells, and with the known deficient IL-2 production in lupus (35). The absence of the $\zeta$ chain in NK cells may also influence their function, which is also decreased in lupus patients $(36,37)$.

One aspect of $\mathrm{T}$ cell physiology which is influenced significantly by the absence of the $\zeta$ chain is the positive and negative selection of the immature thymus-dependent cells. The amplification effects of the three ITAMs of the $\zeta$ chain in signaling are considered important and are supported by experimental data stemming from the study of these selection processes. Absence of the $\zeta$ chain decreases both positive and negative selection. This may apply to SLE as well. The decreased negative selection may enhance an autoimmune repertoire, and the decreased positive selection may be the basis for the decreased thymus-dependent immune responses known in lupus $\mathrm{T}$ cells in vitro and in vivo. Further support for the former hypothesis comes from a recent study reporting an enhanced autoimmune potential for the $\mathrm{T}$ cells produced by $\zeta$-knockout mice (38).

The TCR/CD3-induced signaling in mature $\zeta$-less $\mathrm{T}$ cells has been studied in the setting of tumor-infiltrating lymphocytes by proliferation assays and was found decreased (39). Nevertheless, the $\zeta$ chain deficiency in the above cells was accompanied by decreased expression of src family members which may offer an explanation to this phenomenon. On the other hand, while the levels or the activities of src-PTK in lupus T cells are unknown, the T cells of SLE patients display a decreased counterregulatory mechanism for signal transduction that may contribute to the enhanced Ag receptor signaling events. This consists of the decreased activity of cAMPdependent protein kinase A type I (40). This enzyme negatively affects TCR/CD3-mediated signaling by decreasing the $\mathrm{Ca}^{2+}$ fluxes, and presumably also the anti-CD3 mAb-induced protein tyrosyl phosphorylation. In mature $\mathrm{T}$ cells the TCR $\zeta$ chain is particularly effective in triggering activation-induced cell death (41). This particular mode of TCR/CD3-mediated apoptotic cell death is reportedly decreased in peripheral $\mathrm{T}$ cells of SLE patients in a disease-specific fashion (42), a phenomenon which may be explained by a deficient expression of the $\zeta$ chain in these cells.

Thus, abnormalities in the expression of the TCR $\zeta$ protein may consist of a common denominator in signal dysregulation and in the dysfunction of $\zeta$ chain-bearing immune cells in SLE. Our TCR $\zeta$ mRNA findings imply that this specific mRNA was either absent or abnormal, or finally, extremely unstable and selectively degraded. Further studies are necessary to investigate these possibilities. They also raise the possibility that the underlying abnormality may lie at the DNA level. Analysis of the gene for the TCR $\zeta$ chain, which is located on chromosome 1 , in lupus patients and their families should be the next step to further characterize the observed defect. Genetic factors are well known contributors for SLE, and a possible link with a locus on human chromosome 1 has recently been claimed (43).

In this study, we report for the first time that the TCR $\zeta$ protein is either absent or expressed at greatly decreased levels in 
the majority of patients with SLE. This abnormality is disease specific, disease activity independent, treatment unrelated, and does not represent posttranslational modifications. Because these aberrations were limited to lupus T cells, we conclude that they may represent intrinsic defects of potential pathogenetic significance for the disease.

\section{Acknowledgments}

We are grateful to Dr. L.E. Samelson (National Institutes of Health, Bethesda, MD) for providing the rabbit anti-TCR $\zeta$ antibody 387 . We also thank Dr. M. Tolnay for help with the PhosphorImager and Mr. Lee Collins for help with the preparation of the figures.

This study was supported in part by work unit 9297 from the Department of Clinical Investigation, Walter Reed Army Medical Center.

The opinions and assertions contained herein are the private views of the authors and are not to be construed as official or as reflecting the views of the Department of the Army or the Department of Defense.

\section{References}

1. Weiss, A., and D.R. Littman. 1994. Signal transduction by lymphocyte antigen receptors. Cell. 76:263-274.

2. Wange, R.L., and L.E. Samelson. 1996. Complex complexes: signaling at the TCR. Immunity. 5:197-205.

3. Tsokos, G.C. 1992. Overview of cellular immune function in systemic lupus erythematosus. In Systemic Lupus Erythematosus. R.G. Lahita, editor. Churchill Livingstone, New York. 15-50.

4. Horwitz, D.A., and W. Stohl. 1993. Abnormalities in T lymphocytes. In Dubois Lupus Erythematosus. D.J. Wallace and B.H. Hahn, editors. Lea \& Febiger, Philadelphia. 83-96.

5. Vassilopoulos, D., B. Kovacs, and G.C. Tsokos. 1995. TCR/CD3 complex-mediated signal transduction pathway in $\mathrm{T}$ cells and $\mathrm{T}$ cell lines from patients with systemic lupus erythematosus. J. Immunol. 155:2269-2281.

6. Liossis, S.N.C., B. Kovacs, G. Dennis, G.M. Kammer, and G.C. Tsokos. 1996. B cells from patients with systemic lupus erythematosus display abnormal antigen receptor-mediated signal transduction events. J. Clin. Invest. 98:25492557.

7. Tan, E.M., A.S. Cohen, J.F. Fries, A.T. Masi, D.J. McShane, N.F. Rothfield, J.G. Schaller, N. Talal, and R.J. Winchester. 1982. The 1982 revised criteria for the classification of systemic lupus erythematosus. Arthritis Rheum. 25: $1271-1277$.

8. Bombardier, C., D.D. Gladman, M.B. Urowitz, D. Caron, and C.H Chang. 1992. Derivation of the SLEDAI. A disease activity index for lupus patients. Arthritis Rheum. 35:630-640.

9. Anderson, P., M.L. Blue, C. O'Brien, and S.F. Schlossman. 1989. Monoclonal antibodies reactive with the T cell receptor $\zeta$ chain: production and characterization using a new method. J. Immunol. 143:1899-1904.

10. Weissman, A.M., D. Hou, D.G. Orloff, W.S. Modi, H. Seuanez, S.J. O'Brien, and R.D. Klausner. 1988. Molecular cloning and chromosomal localization of the human $\mathrm{T}$ cell receptor zeta chain: distinction from the molecular CD3 complex. Proc. Natl. Acad. Sci. USA. 85:9709-9713.

11. Ponte, P., S.Y. Ng, J. Engel, P. Gunning, and L. Kedes. 1984. Evolutionary conservation in the untranslated regions of actin mRNAs: DNA sequence of a human beta-actin cDNA. Nucleic Acids Res. 12:1687-1696.

12. Taupin, J.L., and P. Anderson. 1994. Activation-induced proteolysis of cytoplasmic domain of zeta in $\mathrm{T}$ cell receptors and $\mathrm{Fc}$ receptors. Eur. J. Immunol. 24:3000-3004.

13. Mizoguchi, H., J.J. O'Shea, D.J. Longo, C.M. Loeffler, D.W. McVicar, and A.C. Ochoa. 1992. Alterations in T cell transduction molecules in T lymphocytes from tumor-bearing mice. Science. 258:1795-1797.

14. Nakagomi, H., M. Petersson, I. Magnusson, C. Juhlin, M. Matsuda, H. Mellstedt, J.L. Taupin, E. Vivier, P. Anderson, and R. Kiessling. 1993. Decreased expression of the signal transducing $\zeta$ chains in tumor-infiltrating T cells and NK cells of patients with colorectal carcinoma. Cancer Res. 53:5610-5612.

15. Matache, M., M. Stefanescu, A. Onu, G. Szegli, M. Barel, S. Tanaseanu, I. Matei, S. Bouillie, and R. Frade. 1996. Tyrosine phosphorylation in peripheral lymphocytes from patients with systemic lupus erythematosus. Autoimmunity. 24:217-228.

16. Ohno, H., T. Aoe, S. Taki, D. Kitamura, Y. Ishida, K. Rajewsky, and T. Saito. 1993. Development and functional impairment of T cells in mice lacking

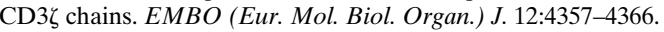

17. Shores, E.W., K. Huang, T. Tran, E. Lee, A. Grinberg, and P.E. Love. 1994. Role of TCR zeta chain in T cell development and selection. Science. 266: 1047-1050.

18. Irving, B.A., and A. Weiss. 1991. The cytoplasmic domain of the T cell receptor $\zeta$ chain is sufficient to couple to receptor-associated signal transduction pathways. Cell. 64:891-901.

19. Chan, A.C., M. Iwashima, C.W. Turck, and A. Weiss. 1992. ZAP-70: a $70 \mathrm{kD}$ protein tyrosine kinase that associates with the TCR $\zeta$ chain. Cell. 71 : 649-662.

20. van Oers, N.S.C., and A. Weiss. 1995. The Syk/ZAP-70 protein tyrosine kinase connection to antigen receptor signaling processes. Semin. Immunol. 7 227-236.

21. Ohno, H., and T. Saito. 1990. CD3 zeta and eta chains are produced by alternative splicing from a common gene. Int. Immunol. 2:1117-1119.

22. Qian, D., A. Sperling, D.W. Lancki, T. Tatsumi, A. Barrett, J.A. Bluestone, and F.W. Fitch. 1993. The $\gamma$ chain of the high-affinity receptor for $\mathrm{IgE}$ is a major functional subunit of the T cell antigen receptor complex in $\gamma \delta \mathrm{T}$ lymphocytes. Proc. Natl. Acad. Sci. USA. 90:11875-11879.

23. Koyasu, S., L. D'Adamio, A.R.M. Arulanandam, S. Abraham, L.K. Clayton, and E.L. Reinherz. 1992. T cell receptor complexes containing FceRI $\gamma$ homodimers in lieu of $\mathrm{CD} 3 \zeta$ and $\mathrm{CD} 3 \eta$ components: a novel isoform expressed on large granular lymphocytes. J. Exp. Med. 175:203-209.

24. Küster, H., H. Thomson, and J.P. Kinet. 1990. Characterization and expression of the gene for the human $\mathrm{Fc}$ receptor $\gamma$ subunit. Definition of a new gene family. J. Biol. Chem. 265:6448-6452.

25. Vivier, E., N. Rochet, J.P. Kochan, D.H. Presky, S.F. Schlossman, and P. Anderson. 1991. Structural similarity between Fc receptors and T cell receptors: expression of the gamma subunit of Fc epsilon RI in human T cells, natura killer cells, and thymocytes. J. Immunol. 147:4263-4270.

26. Anderson, P., M. Caligiuri, J. Ritz, and S.F. Schlossman. 1989. CD3-negative natural killer cells express $\zeta$ TCR as part of a novel molecular complex. Nature. 341:159-162.

27. Lanier, L.L., G. Yu, and J.H. Phillips. 1989. Co-association of CD3ל with a receptor (CD16) for IgG Fc on human natural killer cells. Nature. 342: 803-805.

28. Tsokos, G.C., and J.E. Balow. 1984. Cellular immune responses in systemic lupus erythematosus. Prog. Allergy. 35:93-161.

29. Shores, E.W., V. Flamand, T. Tran, A. Grinberg, J.P. Kinet, and P.E. Love. 1997. Fc $\in \mathrm{RI} \gamma$ can support T cell development and function in mice lacking endogenous TCR $\zeta$ chain. J. Immunol. 159:222-230.

30. Shores, E.W., and P.E. Love. 1997. TCR $\zeta$ chain in T cell development and selection. Curr. Opin. Immunol. 9:380-389.

31. Letourneur, F., and R.D. Klausner. 1992. Activation of T cells by a tyrosine kinase activation domain in the cytoplasmic tail of CD3E. Science. 255 $79-82$.

32. Hermans, M.H.A., and B. Malissen. 1993. The cytoplasmic tail of the T cell receptor $\zeta$ chain is dispensable for antigen-mediated T cell activation. Eur. J. Immunol. 23:2257-2262.

33. Isakov, N., R.L. Wange, W.H. Burgess, J.D. Watts, R. Aebersold, and L.E. Samelson. 1995. ZAP-70 binding specificity to T cell receptor tyrosinebased activation motifs: the tandem SH2 domains of ZAP-70 bind distinct tyrosine-based activation motifs with varying affinity. J. Exp. Med. 181:375-380.

34. Olivier, J.M., D.L. Burg, B.S. Wilson, J.L. McLaughlin, and R.L. Geahlen. 1994. Inhibition of mast cell FceRI-mediated signaling and effector function by the Syk-selective inhibitor, piceatannol. J. Biol. Chem. 269:2969729703.

35. Alcocer-Varela, J., and D. Alarcon-Segovia. 1982. Decreased production of and response to interleukin-2 by cultured lymphocytes from patients with systemic lupus erythematosus. J. Clin. Invest. 69:1388-1392.

36. Hoffman, T. 1980. Natural killer function in systemic lupus erythematosus. Arthritis Rheum. 23:30-35.

37. Tsokos, G.C., A.H. Rook, J.Y. Djeu, and J.E. Balow. 1982. Natural killer cells and interferon responses in patients with systemic lupus erythematosus. Clin. Exp. Immunol. 50:239-245.

38. Yamazaki, T., H. Arase, S. Ono, H. Ohno, H. Watanabe, and T. Saito. 1997. A shift from negative to positive selection of autoreactive $T$ cells by the reduced level of TCR signal in TCR-transgenic CD3zeta-deficient mice. J. Immunol. 158:1634-1640.

39. Finke, J.H., A.H. Zea, J. Stanley, D.L. Longo, H. Mizoguchi, R.R Tubbs, R.H. Wiltroud, J.J. O'Shea, S. Kudoh, E. Klein, et al. 1993. Loss of T cell receptor zeta chain and p56lck in T cells infiltrating renal cell carcinoma. Cancer Res. 53:5613-5616.

40. Kammer, G.M., I. Khan, and C. Malemud. 1994. Deficient type I protein kinase A isozyme activity in systemic lupus erythematosus T cells. J. Clin. In vest. 94:422-430.

41. Combadière, B., M. Freedman, L. Chen, E.W. Shores, P. Love, and M.J. Lenardo. 1996. Qualitative and quantitative contributions of the T cell receptor $\zeta$ chain to mature T cell apoptosis. J. Exp. Med. 183:2109-2117.

42. Kovacs, B., D. Vassilopoulos, S.A. Vogelgesang, and G.C. Tsokos. 1996. Defective CD3-mediated cell death in activated T cells from patients with systemic lupus erythematosus: role of decreased intracellular TNF- $\alpha$. Clin. Immunol. Immunopathol. 81:293-302.

43. Tsao, B.P., R.M. Cantor, K.C. Kalunian, C.J. Chen, R. Singh, D.J. Wallace, R.C. Kitridou, S.I. Chen, N. Shen, Y.W. Song, et al. 1997. Evidence for linkage of a candidate chromosome 1 region to systemic lupus erythematosus (SLE). J. Clin. Invest. 99:725-731. 